\title{
Azerbaycan Ekonomisinde Fiyat Oluşumunda Tarif Şurasının Rolü
}

\author{
The Role of the Tariff Council in Price Formation in the Azerbaijan \\ Economy
}

\author{
Ufuk Selen ${ }^{1}$
}

Orhan Samadzade ${ }^{2}$

\section{ARTICLE INFO \\ Submitted : 02.05.2018 \\ Revised : 12.07.2018 \\ Accepted : 16.07.2018 \\ Available : 30.07 .2018}

JEL classification:

E64, G18, P22, P35

Keywords:

Price, Market

Economy, Tariff

Council, Transition

Economy, Azerbaijan

\begin{abstract}
A B S T R A C T
After the collapse of the Soviet Socialist Republics (Soviet Union), the countries that gained their independence had entered the transition period from centralized economic system towards market economy. Azerbaijan is one of the countries involved in this process since the 1990s. The study's aim is to assess the operation of Azerbaijan by establishing the structure of the price mechanism in transition process towards capitalist economic system. Prior to the study, the basic mechanism of market economy was emphasized and the mechanism of price was explained. In this framework, the features of price formation in terms of market types are considered and emphasis is placed on public pricing strategies as well as models. Public pricing is implemented in a manner that would serve different purposes. These can be expressed in terms of minimizing the welfare losses caused by market failures and/or contributing to public financing. Following the explanation of price mechanism, the study stresses the process of transition to Azerbaijan's market economy and the basic macroeconomic situation of the country. At an institutional level, prices in Azerbaijan are determined by "Tarif Şurası" (Tariff Council). It is not unfair to say that the basic functioning of price mechanism in Azerbaijan has been defined as the provision of public financing. It can be considered that pricing policy is followed by public pricing due to weakness of GDP growth and lowness of tax capacity.
\end{abstract}

1 Assoc. Prof. Dr. (https://orcid.org/0000-0002-1337-8294), Bursa Uludağ University, Faculty of Economics and Administrative Sciences, Department of Public Finance, Turkey, uselen@uludag.edu.tr

2 Master student, (https://orcid.org/0000-0003-3870-8218), Bursa Uludağ University, Institute of Social Sciences, Department of Public Finance, Turkey, s.orxan.n@mail.ru 
Selen, U. \& O. Samadzade (2018). "Azerbaycan Ekonomisinde Fiyat Oluşumunda Tarif Şurasının Rolü”, International Journal of Public Finance, Vol.3, No.1, pp. 83-106.

\begin{tabular}{ll}
\multicolumn{2}{l}{ MAKALE Bilgisi } \\
\hline Gönderme: 02.05 .2018 \\
Düzeltme $: 12.07 .2018$ \\
Kabul $\quad: 16.07 .2018$ \\
Yayın $\quad: 30.07 .2018$
\end{tabular}

JEL Kodu:

E64, G18, P22, P35

\section{Anahtar Kelimeler:}

Fiyat, Piyasa

Ekonomisi, Tarif

Şurası, Geçiş

Ekonomisi, Azerbaycan

\begin{abstract}
Ö Z E T
Sovyet Sosyalist Cumhuriyetler Birliği (SSCB) dağıldıktan sonra bağımsızlıklarını kazanan ülkeler, merkezi planlı ekonomik sistemden piyasa ekonomisine geçiş sürecine girmişlerdir. Azerbaycan da 1990'। yıllarda bu sürece dahil olan ülkelerdendir. Çalışmanın amacı, Azerbaycan'ın kapitalist ekonomik sisteme geçiş sürecinde oluşan fiyat mekanizmasının yapısını ortaya koyarak, işleyişinin değerlendirilmesi olarak belirlenmiştir. Çalışmada önce piyasa ekonomisinin temel özelliklerine vurgu yapılarak, fiyat mekanizmasının işleyişi açıklanmıştır. Bu çerçevede piyasa türleri açısından fiyat oluşumunun özellikleri ele alınarak, kamusal fiyatlama stratejileri ve modelleri üzerinde durulmuştur. Kamusal fiyatlama farklı amaçlara hizmet edecek biçimde yapılmaktadır. $\mathrm{Bu}$ amaçlar; piyasa aksaklığının neden olduğu refah kayıplarını en aza indirmek ve/veya kamu finansmanına katkı sağlamak biçiminde ifade edilebilir. Çalışmada Azerbaycan'ın piyasa ekonomisine geçiş süreci ve ülkenin temel makroekonomik durumu hakkında bilgi verildikten sonra fiyat mekanizmasının işleyişi açıklanmıştır. Azerbaycan'da fiyatlar "Tarif Şurası" olarak isimlendirilen kurumsal yapı içinde belirlenmektedir. Azerbaycan'da fiyat mekanizmasının temel işleyiş amacının kamu finansmanın sağlanması olarak belirlendiğini söylemek yanlış olmayacaktır. GSYH artırma gücünün zayıf ve dolayısıyla vergi kapasitesi düşük olduğu için kamusal fiyatlama ağılıklı bir fiyat politikası izlendiği ifade edilebilir.
\end{abstract}

\section{Giriş}

Kapitalist ekonomik sistemin işleyişi rekabet koşullarına uygun kurgulanmış bir fiyat mekanizması ile anlam kazanmaktadır. Arz ve talebin dışında hiçbir unsurun fiyat oluşumuna müdahalesi istenmemektedir. Ancak, gerçek ekonomik yaşam bu teorik ön görüye uymamaktadır. Fiyat, farklı biçimde gözlenen piyasa aksaklıklarında oluşmaktadır. Piyasa aksaklıkları geçiş ekonomilerinde daha fazla gözlenmektedir. Çalışmanın amacı merkezi planlı ekonomiden piyasa ekonomisine geçen Azerbaycan ekonomisinin fiyat mekanizmasının işleyişini tam rekabet piyasası özellikleri açısından değerlendirmektir. Kapitalist ekonomilerde ekonomik birimler kararlarını fiyata bakarak alırlar. Diğer bir ifade ile ne üreteceklerine, ne kadar üreteceklerine ve kim için üretim gerçekleştireceklerine fiyata bakarak karar verirler. Hiç bir otoritenin fiyat oluşumuna müdahalesi istenmemektedir. Ancak, ekonomik gelişmişlik düzeylerinin farklı olması ülkelerin fiyat oluşumuna farklı biçimlerde müdahale etmelerine neden olmaktadır. Piyasa ekonomisi kurum ve kurallarının oturtulmaya çalışıldığı ekonomilerde bu durum daha çok gözlenmektedir. Bu niteliğe sahip Azerbaycan ekonomisinde fiyat oluşumunun piyasa ekonomisi kuralları açısından incelenmesi çalışmanın temel amacını oluşturmaktadır.

Çalışmada ilk önce piyasa ekonomisinin temel özellikleri, piyasa türleri açısından fiyat oluşumu incelenecektir. Esas incelemeye girecek piyasa türü tam rekabet piyasası 
ve bu piyasanın özellikleridir. Fiyat oluşumunun piyasa koşullarında nasıl gerçekleştiği ve kamusal fiyat oluşumunun özellikleri üzerinde durulacaktır.

Piyasa ekonomisine genel bir bakıştan sonra Azerbaycan ekonomisinin genel görünümü ve Azerbaycan ekonomisinde fiyat oluşumu daha detaylı incelenecektir. Bu bağlamda önce Azerbaycan ekonomisinin merkezi planlı ekonomiden kapitalist ekonomik sistemine geçiş süreci ele alınarak, piyasa ekonomisi şartlarının işler hale getirilme süreci ve genel ekonomik yapı makroekonomik büyüklükler üzerinden değerlendirilecektir.

Azerbaycan ekonomisinin genel yapısı ortaya koyulduktan sonra fiyat oluşumunda önemli yetkilere sahip olan Tarif Şurası'nın yapısı, işleyişi ve karar alma süreci piyasa ekonomisi ilkeleri özelinde değerlendirilerek çalışma sonlandırılacaktır.

\section{Piyasa Ekonomisinin Temel Özellikleri}

Ekonomi, kaynak tahsis ve yönetim problemi ile ilgilenmektedir. Kaynak tahsis ve yönetiminin nasıl olması gerektiği ile ilgili yaklaşım "sosyalist ekonomi" ve "kapitalist ekonomi" olmak üzere iki yaklaşımla ele alınmaktadır. Sosyalist ekonomi kaynak tahsis ve yönetiminin ortak mülkiyet temelinde, merkezi planlamaya dayalı biçimde gerçekleştirilmesi gerektiği fikrinden hareket etmektedir (Dinler, 2015a: 39). Diğer taraftan kapitalist ekonomik sistem ise meseleyi özel mülkiyeti esas alan ve bireyin iradesine dayanan bir yaklaşımla ele almaktadır. Kapitalist ekonomik sistem yaklaşımında ekonomik birimler, mülkiyetleri altındaki, kaynak tahsisine ilişkin kararlarını özgür iradeleriyle vermelidir (Dinler, 2015a: 34).Ekonomik birimlerin karşılaştıkları platformlar piyasa, kaynakların değişim değeri ise fiyat olarak isimlendirilmektedir. Bu nedenle kapitalist ekonomik sistem çoğunlukla piyasa ekonomisi olarak da isimlendirilmektedir. Biz de bu çalışmada piyasa ekonomisi kavramsallaştırmasını kullanacağız.

Piyasa ekonomisi, yatırım üretim ve dağıtım ile ilgili kararların arz ve talebe dayalı olduğu, mal ve hizmet fiyatlarının serbest fiyat sistemi içinde belirlendiği ekonomidir. Çoğu mevcut piyasa ekonomisi belirli bir dereceye kadar ekonomik planlama veya devletin ekonomik aktiviteleri yönlendirmesini içerir ve dolayısıyla karma ekonomi olarak sınıflandırılır.

Piyasa ekonomisi kavramı ilk olarak, başlarında Adam Smith olmak üzere, Anglosakson kökenli iktisatçılar tarafından ilme sürülmüştür. Smith'e göre her şey piyasanın kendi kuralları içerisinde cereyan etmeli, devlet ise sadece adalet, hürriyet ve mülkiyetle ilgili geleneksel görevleri içerisinde kalmalıdır. Diğer bir ifadeyle devlet tam kamusal mallarla sınırlı bir alan içinde ekonomik yaşama müdahale etmelidir.

Piyasa ekonomisi, rekabet kavramından hareketle kaynakların tahsis ve yönetiminin en uygun biçimde dağıtılabileceği esasına dayanmaktadır. Ekonomik birimler arasındaki rekabet fiyatların en düşük düzeyde oluşmasına ve böylece en az kaynakla en yüksek miktarda ihtiyacın karşılanması mümkün olabilecektir. Diğer 
taraftan rekabet dolayısıyla en düşük maliyetle üretime yönelen ekonomik birimler kaynak kullanım etkinliğini de sağlamış olacaktır. Rekabetçi piyasalarda alıcılar, mallar için atfettikleri değeri aşmayacak bir fiyat ödemeyi kabul ederlerken, satıcılar da malın üretim değerini karşılamayacak bir fiyatı kabul etmeyeceklerdir. Böyle bir sistemde artık üretim ortaya çıkmayacaktır. Çünkü, üreticiler artık üretimi karlı fiyattan satamayacaklarını çabuk kavrarlar. Diğer yandan, uzun süreli bir eksik üretim de meydana gelmez. Zira herhangi bir kıtlık, alıcıların daha yüksek bir fiyat teklif etmelerine neden olur ki bu da arzı arttırır. Serbest piyasa sisteminde Adam Smith'in görülmez el olarak kavramlaştırdığı fiyat mekanizmasının, sadece tüketim mal ve hizmetlerinin fiyatını değil, bunları elde etmek için kullanılan ham madde, emek gibi temel girdilerin de fiyatını belirler.

Rekabetçi bir ortamda bu sonuçların elde edilebilmesi için piyasaların, "atomisite", "mobilite", "homojenite" ve "açıklık" özelliklerine sahip olması gerekmektedir. Bu özelliklerin taşıdığı anlam ve önemi kısaca aşağıdaki gibi özetlemek mümkündür.

Atomisite, her ekonomik birimi maddenin atomları olarak ele almaktadır. Yani atomisite, piyasada çok sayıda alıcı ve satıcının işlem yapması gerektiğini söyler. Piyasada çok sayıda alıcı ve satıcının var olması fiyatın veri olarak alınmasına imkan sağlayacaktır. Piyasada ekonomik birim sayısının artması birimler arası ortak hareket etmek imkanını ortadan kaldıracak ve her birey kendi gerçeğinden hareketle karar verecektir. Böylece hiçbir satıcı ya da alıcı tek başına fiyatı belirleyemeyecektir. Hiçbir firma pazarın büyük bir kısmını elinde bulunduramaz. Aynı zamanda alıcılar da tek başlarına fiyatı belirlemek yetkisine sahip değildirler, çünkü bir alıcı malın tamamını ve ya büyük bir kısmını alacak güce sahip değildir. Bu durumda fiyat piyasa veri olarak ortaya çıkacak ve ekonomik birimler fiyatı piyasadan öğrenecektir. Çok sayıda alıcı ve satıcı arasında yaşanan rekabet ekonomik birimlerin maliyet minimizasyonuna yönelmelerini ve fiyatın en alt düzeyde gerçekleşmesine imkan sağlayacaktır. Sonuçta fiyat neredeyse firmanın üretim maliyetine yaklaşacaktır ve ortada sadece düşük kar kalacaktır. Öyle ki, teorik olarak tam rekabet piyasasında ekonomik kar sıfır olarak kabul edilmektedir. (Dinler, 2015b: 74).

Mobilite, piyasalar arası geçişgenliği tanımlamak için kullanılmaktadır. Fayda maksimizasyonu peşinde koşan ekonomik birimlerin her piyasaya girebilmesi gerekliliğine işaret etmektedir. Ekonomik birimlerin mobilizasyonu piyasalar arası arz ve talep dengesinin sağlanmasını garanti etmektedir. Dolayısıyla piyasalar arası geçişgenlik arttıkça arz ve talep fazlalıkları eritilebilecek ve fiyatın tüm piyasalar için aynı olması sağlanmış olacaktır. Böylece, piyasalarda görece kıtlık farkından doğan aşırı karlar törpülenerek rekabetten sapmalar önlenmiş olacaktır.

Homojenite, değişime konu ürünlerin birimlere ayrılabildiğini ve bir malın fiyatından bahsedildiğinde tüm piyasalarda o malın aynı özelliklere sahip olması gerekmektedir. Örneğin yağıı inek sütünün fiyatı 2 TL denildiğinde, sütün litre bazında bölünebildiği ve Türkiye genelinde işlem gördüğü her piyasada 2 TL'lik fiyatın yağlı inek sütü için geçerli olması anlamına gelmektedir. Şayet sütün litresi 1,5 TL olduğu belirtilmiş ise bu iki anlam taşıyabilir. Bunlardan ilki iki farklı fiyata konu sütün homojen 
olmadığıdır. Bu durumda sütün kalitesine bağlı fiyat farklılaşmasından bahsedilebilir ki her kalite için geçerli fiyat sütlerin işlem gördüğü piyasalarda aynı olacaktır. Bu homojenlik özelliğinin gereğidir. Diğer bir olasılık ise piyasalar arası mobilizasyon veya açıklıkla ilgili bir sorunun olduğudur.

Açıklık, piyasalar arası geçişgenlik açısından aranan bir özelliktir. Ekonomik birimler piyasalar hakkında bilgiden hareketle kararlarını vermekte ve piyasalar arasında gezinerek fiyatın tüm piyasalar için sabitlenmesine imkan sağlamaktadır. Bunun gerçekleşebilmesi için bilginin ekonomik birimler arasında mükemmel biçimde dağılması gerekmektedir. Mükemmellikten kasıt bilgi dolaşımının serbest ve akışında herhangi bir gecikmenin olmamasıdır. Böylece ekonomik birimlerin kararlarını etkileyen fiyat ve fiyat oluşumu hakkında tam ve doğru bilgi elde edilmiş olacaktır.

Bu dört özelliğin zaman ve mekan olarak tüm piyasalarda geçerliliğinin sağlanması mümkün olmamaktadır. Gerek değişime konu malların teknik özellikleri, üretim koşulları, mülkiyet yapıları ve gerekse ülke ekonomisinin sahip olduğu sosyal ve ekonomik yapılara tam rekabet piyasasından sapmalara neden olmaktadır. Tam rekabet piyasasından sapmalar, kamusal malların varlığı, doğal tekel koşullarında üretim zorunluluğu, dışsallıkların varlığı ve asimetrik bilginin önlenmesi biçiminde sistematize edilmektedir.

Piyasa aksaklıklarının gözlendiği alanlarda piyasalar tekelleşme eğilimiyle hareket etmektedir. Bu eğilim de, tam rekabet piyasası hariç, "tekel piyasası", "oligopol piyasası" ve "monopolcü rekabet piyasası" olmak üzere üç farklı piyasa yapısını ortaya çıkarmaktadır. Bu tür aksak piyasalarda ortaya çıkan haksız rekabeti önleyecek ve fiyat oluşumunu piyasa koşullarına yaklaştıracak piyasa yapıcı bir otoriteyi gereksinim vardır. Tüm ekonomik birimlerin üzerinde güç kullanma yetkisiyle donatılan bu otorite ancak devlet olmaktadır. Devlet, kamu işletmeciliği ve/veya düzenleyici ve denetleyici faaliyetlerle piyasa aksaklıklarını önlemeye çalışmaktadır. Dolayısıyla kapitalist ekonomik sistemde, ekonomideki kaynak tahsis işlevini yerine getirmede piyasa yapıcılığı devlete bir görev olarak yüklenmiştir. Devlet, düzenleyici ve denetleyici faaliyetleriyle piyasalarda tam rekabet koşullarını hakim kılmaya çalışırken, kamu ekonomisi faaliyetleriyle özellikle doğal tekel alanlarında kamusal fiyatlama politikalarıyla piyasalarda kaynak tahsisini yönetip yönlendirmektedir.

\section{Fiyat Oluşumu ve Kamusal Fiyatlama}

\subsection{Fiyat Kavramı ve İşlevleri}

Fiyat, ekonomik sistemler tarafından farklı biçimlerde tanımlanmaktadır. Özünde fiyat mal ve hizmetlerin değişim değerini ifade etmektedir. Tanımlanmasındaki farklıık değişim değerinin taşıdığı anlamla ilgilidir. Kapitalist ekonomik sistemde fiyat üretimde kullanılan faktörlerin toplam parasal değeri olarak kabul edilir ve taraflar malların değişiminde bu parasal değeri esas alırlar. Diğer taraftan sosyalist ekonomik sistemde ise fiyat maliyetle ilişkili bir unsur olarak görülmez. Fiyat maliyetten bağımsız, ekonomik birimlerin mala atfettikleri değere karşılık gelmektedir (Salimjanov, 2007: 12). 
Fiyatın fonksiyonlarını aşağıdaki gibi sıralamak mümkündür;

1) fiyat maliyetlerin parasal değerini temsil eder,

2) fiyat ekonomik birimleri teşvik edici özelliğe sahiptir,

3) fiyat, bölüşüm ilişkilerini etkileme özelliğine sahiptir. Piyasa aksaklıklarının gözlendiği alanlarda fiyat maliyetleri temsil etme özelliğini kaybederek bölüşüm ilişkilerini etkiler,

4) Piyasa dengesinin oluşmasına etki eder. Fiyat, arz-talep, üretim-tüketim, yatırım-tasarruf gibi unsurlar arasında kurduğu bağla değişim ilişkisinin gerçekleşmesini sağlar (Herasimenko, 2005: 55-57).

Bu özellikler, fiyatın her ekonomik sistemde merkezi bir rol üstlenmesine imkan sağlar. Bu fiyatın ürünlerin niteliğini temsil etmesinin yanında, piyasa aktörlerinin ekonomik çıkarlarının özünü oluşturmasından kaynaklanır (Salimjanov, 2007: 14).

Fiyat oluşumu teorisi kapitalizmin ilk çağlarından itibaren önem arz etmeye başlamıştır. O zamanlarda bu konuyla William Petty, Adam Smith, David Ricardo gibi iktisatçılar ilgilenmişlerdir. Bu yazarlara göre fiyat ürünün maliyeti üzerinden oluşur, yani fiyat oluşumunda esas rol üretimde kullanılan emeğe atfedilir. Kapitalist ekonomik sistemde fiyat tüm tarafların üzerinde uzlaştıkları ortak paydadır. Fiyat; tüketicilerin malın tüketiminden elde ettikleri faydayı temsil ederken üreticiler için ise bir malın marjinal üretim maliyetine karşılık gelmektedir. Tam rekabet piyasa koşullarında fiyat, marjinal maliyet ve fiyata eşitlenmektedir. Bu eşitlenme atomisite kuralı altında kendiliğinden gerçekleşmekte ve hiçbir alıcı ve satıc fiyata müdahale edememektedir. Fiyatın, tüm ekonomik birimler tarafından veri olarak alındığı kabul edilmektedir.

Fayda maksimizasyonundan hareket eden ekonomik birimler maliyet minimizasyonuna yönelerek fiyatın en düşük seviyede oluşmasına imkan sağlarlar. Öyle $\mathrm{ki}$, maliyet minimizasyon hareketi ekonomik karın sıfır olarak belirlenmesine neden olduğu kabul edilmektedir. Ekonomik karın sıfır olduğu bir ekonomide fiyat doğrudan marjinal maliyete eşitlenecektir.

Şekil 1: Kapitalist Sistemde Fiyat Oluşumu

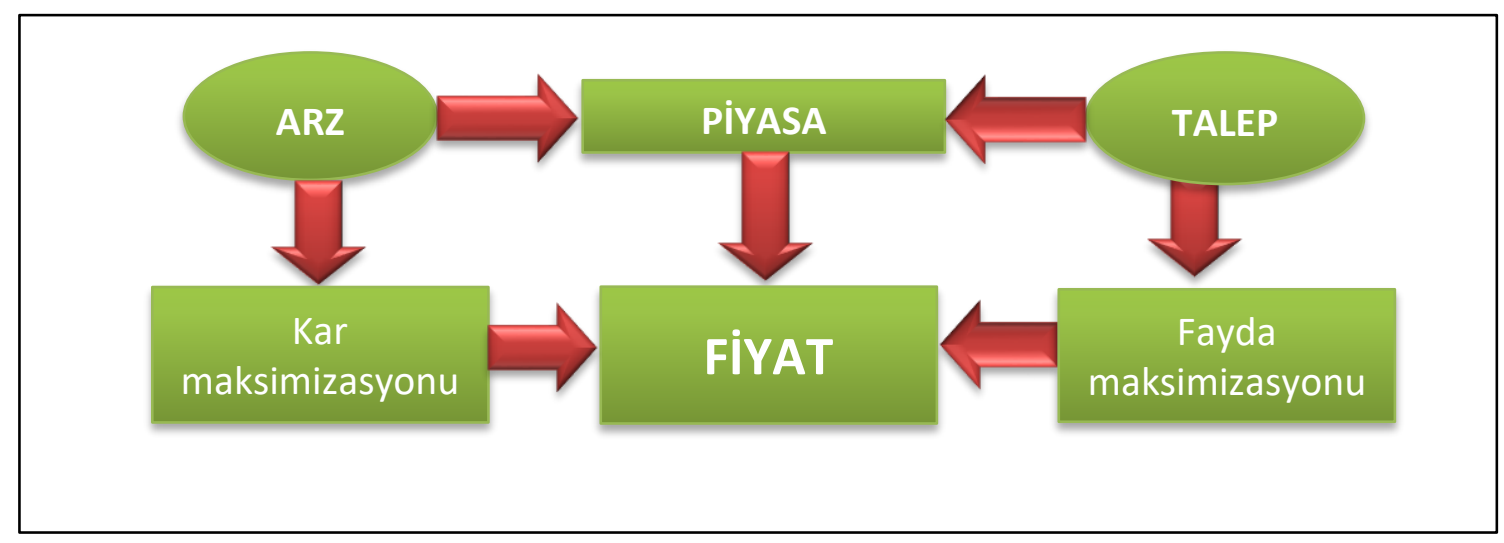


Ancak, Karl Marks fiyat oluşumunu farklı bir yaklaşmışla ele almıştır. Marks'a göre fiyat maliyetle ilişkili bir unsur değildir. Bir ürünün hem maliyeti hem de fiyatı vardır. Bu yaklaşıma göre maliyet üretim sürecinde kullanılan emek miktarından oluşur. Fiyat ise maliyetin parasal değeri olup, farklı piyasa faktörlerinin etkisi altında maliyetten bağımsız bir değer kazanabilir. Bu yaklaşımıyla Marks fiyatı, maliyetten ayırarak, piyasa koşullarına göre farklılaşabilen bir değer olarak görmekte ve fiyatın matematiksel eşitlik olarak maliyete indirgenemeyeceğini savunmaktadır (Marx, 1865: 29). Malın değeri maliyetten bağımsız olarak, arz ve talep esnekliği ile ekonomik birimlerin değer yargıları gibi unsurlardan etkilenmektedir. Dolayısıyla fiyat, çoğu zaman emek maliyetinden büyük olarak belirlenmektedir. Değişim aracı olarak fiyat emeğin ortaya çıkardığı artı değerin, emeği istihdam edende toplanmasına neden olacaktır. Marksist yaklaşım, ekonomiyi analitik bir çerçevede değerlendirerek üretim ve değişim alanlarını birbirinden ayırarak çözümlemelerinin asıl ağırlığını üretim alanına vermektedir (Özel, 2009: 124). Marks bu noktada emeğim üretim değerine kapitalist sınıfın el koyduğu ve emeği sömürdüğü gerekçesiyle üretim faktör mülkiyetinin topluma ait olmasını öngörmektedir. Temel maliyet unsuru olan ücretler emeğin karşılığı olarak ödenirken, sermaye birikiminin itici gücü olan, karlar üretim maliyet unsuru olarak görülmez. Kar üretim maliyetleri dışında kalan bir artığın üretilmesi sonucunda ortaya çıkmaktadır. Sermayeye yapılan ödemeler bu artıktan yapılmakta ve herhangi bir müdahaleye dayanmamaktadır. Yani emeğin üretim sürecinde ortaya çıkarılan değer emekle bölüşülmeyerek doğrudan kapitalist sınıfa aktarılmaktadır. Burada Marksist yaklaşım, klasik yaklaşımın öngördüğü karların rekabetçi piyasalarda sıfırlanma eğiliminde olduğunu kabulüne karşı çıkmaktadır (Özel, 2009: 125). Buradan hareketle fiyatın merkezi planlama yoluyla belirlenmesini önermektedir. Böylece fiyat emeğin değeri dışında unsurlar tarafından belirlenmeyecek ve karların kapitalist sınıfta toplanması engellenerek, emeğin sömürüsü önlenmiş olacaktır.

Görüldüğü gibi iki ana akım iktisadi düşünce de fiyat oluşumu farklı biçimde yorumlanmaktadır. Kapitalist ekonomik sistemde fiyatın maliyetleri temsil ettiği kabul edilirken, sosyalist fiyat modelinde ise maliyetin yanında; mala atfedilen değerinde fiyat oluşumunda etkili olduğu kabul edilmektedir. Çalışmada kapitalist ekonomik sistemi benimsemiş olan Azerbaycan ekonomisinde fiyat mekanizmasının işleyişinin özellikleri ele alınacağı için kapitalist sistemde fiyat oluşumu ve etkileyen unsurların açıklanmasında yarar görülmektedir.

\subsection{Piyasada Fiyat Oluşumunun Özellikleri}

Yukarıda da ifade edildiği gibi, kapitalist ekonomik sistemde fiyat piyasada oluşmakta ve maliyetleri temsil eden bir unsur olarak ele alınıp incelenmektedir. Fiyat oluşumuna ilişkin tüm çözümlemeler tam rekabet piyasa varsayımlarıyla ilişkilendirilmektedir. Oysa piyasa yapıları fiyat oluşumunun gerçekleştiği piyasa yapısına bağlı olarak farklııı göstermektedir. Aşağıda, piyasa yapılarından hareketle fiyat oluşumunun özellikleri incelenecektir. 
Paretocu refah iktisadı, iki temel teorem üzerinde piyasayı kutsamakta ve iktisadın temel sorunu olan tahsis probleminin piyasada en uygun biçimde çözüleceğine vurgu yapmaktadır (Akalın, 2016: 68-72). Birinci temel teoremde tam rekabet piyasa koşullarında gerçekleşen kaynak tahsisi pareto anlamında etkin oluğuna dikkat çekilmektedir. Piyasanın pareto anlamda etkinliği sağlayamadığı durumlarda da piyasa koşullarında kalınarak yapılacak müdahalelerle pareto iyileştirme yapılabileceği ikinci temel teorem olarak kabul edilmektedir. Her iki teoremde de zımni olarak fiyat göstergesi altında gerçekleşen kaynak tahsisinin optimal olacağına dikkat çekmektedir. Birinci temel teorem ideali ortaya koyarken, ikinci temel teorem tam rekabet piyasa koşullarından sapma durumlarında fiyatın piyasa koşullarına yakın oluşmasını garanti altına almayı amaçlamaktadır. Buradan hareketle iki uç piyasa modeli olan tam rekabet piyasası ve tekel piyasa koşullarında fiyat oluşumunu aşağıdaki gibi açıklayabiliriz.

\subsubsection{Tam Rekabet Piyasasında Fiyat Oluşumu}

Tam rekabet piyasa modellemesinde fiyat tüm üretici ve satıcıların hür iradeleri ile şekillenmektedir. Taraflar maliyet minimizasyonuna yönelerek fiyatların en düşük düzeyde oluşmasına gayret gösterir. Dolayısıyla fiyatlar marjinal maliyet düzeyinde oluşmakta ve ekonomik karlılık sıfır olarak gerçekleşmektedir. Tam rekabet piyasasında fiyat ekonomik birimleri piyasada tutacak düzeydedir. Fiyata karşılık gelen marjinal maliyet aslında piyasada gerçekleşen bireysel maliyetlerin ortalama değerini ifade etmektedir. Dolaysıyla piyasa fiyatını temsil eden marjinal maliyetin altında bireysel maliyetle çalışan firmalar faaliyetlerini normal kar düzeyinde sürdürmektedir.

\section{Şekil 2: Tam Rekabet Piyasasında Fiyat Oluşumu}

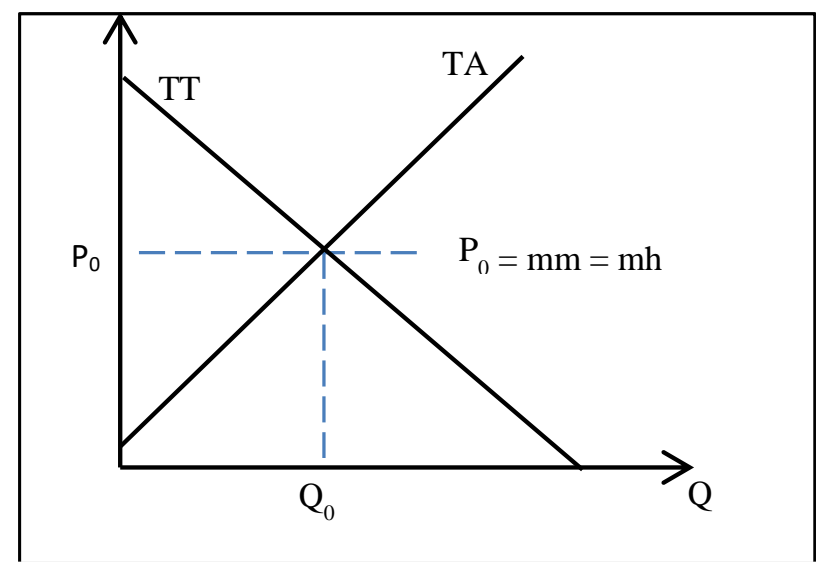

Yandaki şekilde tam rekabet piyasası fiyat oluşumu açıklanmaktadır. Şekilde Alıcı ve satıcılar $P_{0}$ fiyatında alıcılar tüketmek istedikleri kadar malı alabilmekte ve satıcılarda satmak istedikleri kadar malı satabilmektedir. Dolayısıyla tüketiciler en düşük marjinal maliyetle $(\mathrm{mm})$ tüketime, üreticiler ise en üst marjinal hasılaya $(\mathrm{mh})$ ulaşmıştır. " $m m$ " ve " $m h$ " eşitliği yukarıda açıklanan tam rekabet piyasa koşullarının 
geçerli olması halinde sağlanabilmektedir. Arz ve talep yapıları fiyat dışı pek çok unsurdan etkilenebildiği için aslında piyasalar sürekli istikrarsız bir yapıya sahip olup, tekelleşme eğilimi göstermektedir. Piyasaların tam rekabet piyasa koşullarından uzaklaşma eğilimi fiyatın marjinal maliyet fiyatlamasından sapmasına neden olmaktadır.

\subsubsection{Tekel Piyasasında Fiyat Oluşumu}

Tekel piyasalarında, ortaya çıkan piyasaya giriş engelleri atomisite kuralının bozulmasına neden olmuştur. Dolayısıyla fiyat oluşumunda çok sayıda alıcı ve satıcının iradesi belirleyici değildir. Fiyat tek bir ekonomik birim tarafından belirlenmektedir. Tekel piyasalarında arz planlaması yoluyla fiyat belirlenmektedir. Firma, $\mathrm{mm}=\mathrm{mh}$ koşulunun sağlandığı aşamada üretim kapasitesini belirlemektedir. Bu kapasitede üretim için oluşan talep fiyatın belirlenmesine imkan sağlar. Yukarıdaki şekilde $\mathrm{mm}=$ mh eşitliği üretim düzeyinin $Q_{0}{ }^{\prime}$ da belirlenmesini sağlamıştır. Arzın $Q_{0}$ düzeyinde sınırlı tutulması tüketicileri tüketimde rekabete sürükleyerek yüksek fiyat ödemelerine neden olmuştur. Dolayısıyla tekel piyasasında fiyat $\mathrm{P}_{0}$ düzeyinde oluşmuştur. Firma, arz planlaması yardımıyla ortalama maliyeti üzerinde bir fiyattan satış gerçekleştirerek iktisadi anlamda aşırı kar elde etmiştir. Şekil 3'deki taralı alan aşırı karı temsil etmektedir.

Şekil 3: Tekel Piyasasında Fiyat Oluşumu

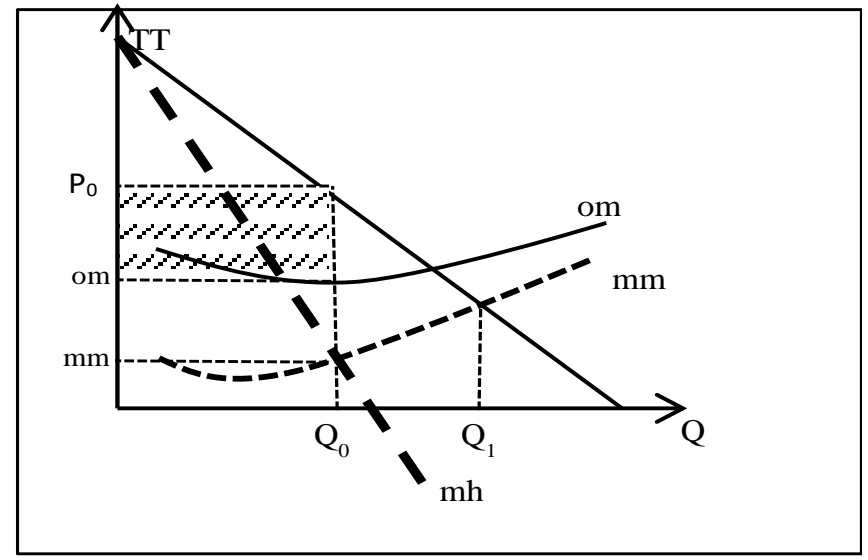

Aksak piyasalarda, firmaların aşırı kara yönelmesi tüketim kaynaklı sosyal refah kayıplarına neden olmaktadır. Şekildeki firma, fiyatını talep düzeyine karşılık gelen marjinal maliyet seviyesinde belirlemiş olsaydı talebe daha fazla cevap vereceği için $\mathrm{Q}_{1}-\mathrm{Q}_{0}$ kadar eksik tüketim ve üretimden kaynaklanan refah kaybı oluşmayacaktı. Refah kayıplarına neden olduğu için piyasa aksaklıklarının devlet eliyle giderilmesi amaçlanmaktadır. Dolayısıyla devlet piyasa aksaklıklarının görüldüğü alanlardaki toplumsal refah kayıplarını en aza indirmek amacıyla kamusal fiyatlama politikaları izleyebilmektedir. Devletin kamusal fiyatlama strateji ve politikalarını aşağıdaki gibi açıklamak mümkündür. 


\subsection{Kamusal Fiyatlama Strateji ve Modelleri}

Kamusal fiyatlama izlenen politika amacına uygun olarak teknik açıdan izlenebilecek üç fiyatlama stratejisinden bahsedilebilir. Bunlar; "tekel fiyatlaması", "ortalama maliyet fiyatlaması" ve "marjinal maliyet fiyatlaması" olarak isimlendirilmektedir. Aşağıda ele alınan bu stratejiler farklı modellerle işlerlik kazanabilmektedir. Aşağıda önce fiyatlama stratejileri ve sonrasında da fiyatlama modelleri hakkında bilgi verilecektir.

\subsubsection{Kamusal Fiyatlama Stratejileri}

Kamusal fiyatlama devletin üreterek ve/veya tedarik ederek topluma sunduğu özel mallar için geçerlidir. Bu tür malların finansmanı, mümkün olduğunca, yararlanan öder ilkesine göre yapılmaktadır. Ancak, çoğunlukla bire bir finansman şeklinde olmamaktadır. Kamusal fiyatlamayla izlenen amaçlar yararlanıcıların katkı düzeyini belirlemektedir. Buna göre kamusal fiyatlamada izlenen olası amaçlar; a) hazineye gelir sağlama, b) toplumsal refah kaybını azaltma, c) bölüşüm ilişkilerini ve d) kaynak tahsisini düzenleme olarak sayılabilir. Karar alıcılar hangi amaçla nasıl bir fiyatlama politikası belirleyeceklerine mala ilişkin arz ve talep fiyat esnekliğine, hizmet sunumunun kamu maliyesinde oluşturacağı yüke ve izleyeceği fiyatlama politikasının oya tahvil gücüne bakarak karar verirler. Kamusal fiyatlamada teknik olarak, "tekel fiyatlaması", "ortalama maliyet fiyatlaması" ve "marjinal maliyet fiyatlaması" olmak üzere üç fiyatlama stratejisi kullanılır. Bunların kamusal fiyatlamanın amaçlarıyla olan ilişkisini aşağıdaki şekil üzerinden açıklamak meseleyi daha anlaşııır kılacaktır.

Şekil 4: Kamusal Fiyatlama Stratejileri

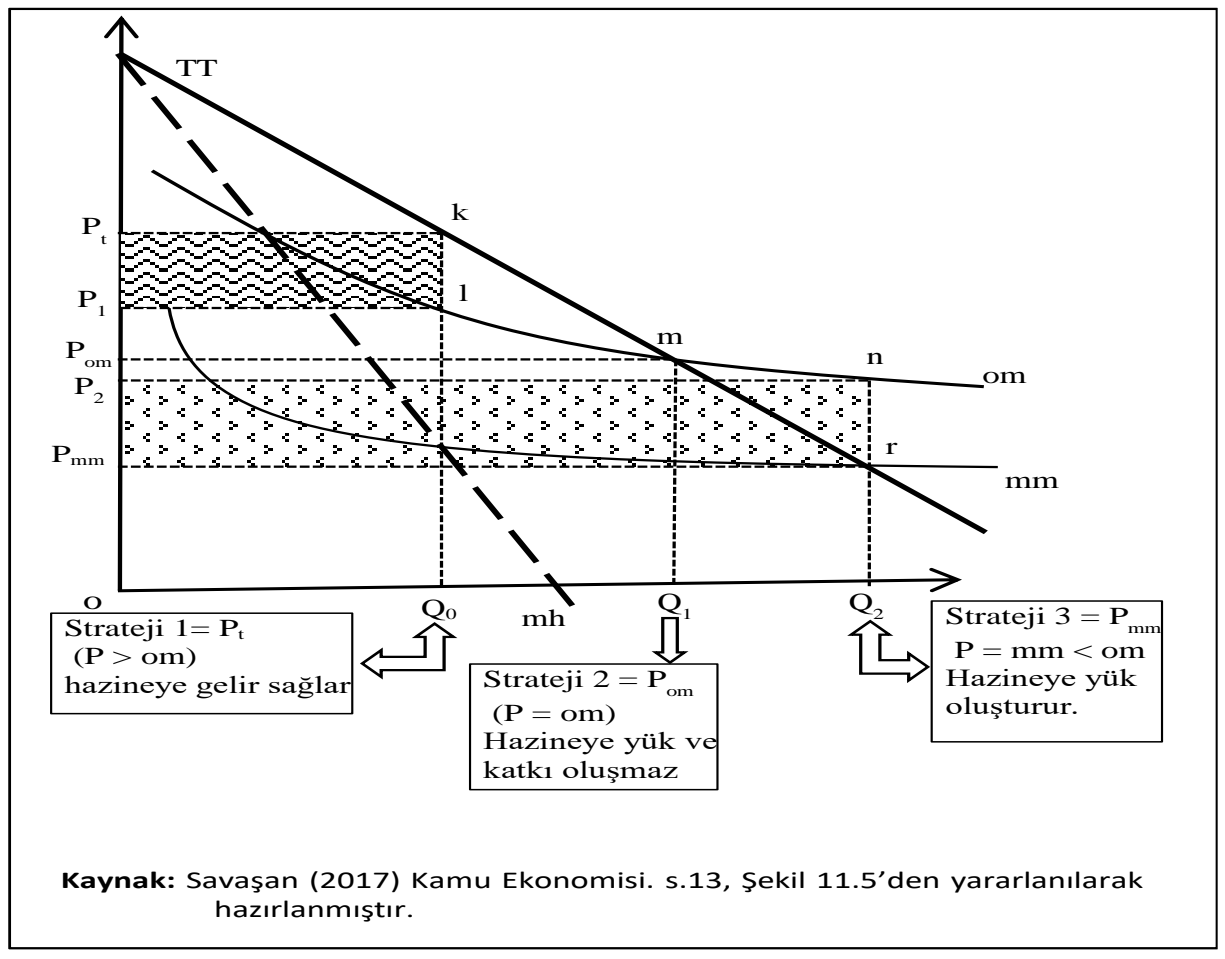


Tekel fiyatlamasında amaç, devletin mülk ve teşebbüs gelirlerini artırmaktır. Özellikle mali kapasitesini geliştirememiş ekonomiler oluşturdukları yasal tekellerle kamu geliri elde etme yoluna gidebilmektedir. Çoğunlukla talebinin fiyat esnekliği düşük mallar alanında oluşturulan yasal tekeller sayesinde yaratılan aşırı karlarla kamu finansmanına önemli katkı sağlanabilir. Tekel karlarıyla gelir elde edilmesinin toplumsal refah kaybına neden olacağı unutulmamalıdır. Dolayısıyla toplumsal refah kaybı tekel fiyatlamasının alternatif maliyetini oluşturmaktadır. Arz planlaması yardımıyla oluşturulan tekel karları talebin yetersiz karşılanmasına neden olmakta ve yetersiz tüketime bağlı fayda kayıpları toplumsal refah kaybı olarak kabul edilmektedir. Tekel fiyatlamasının neden olduğu toplumsal refah kaybı çapraz finansman yoluyla kısmen telafi edilebilir (Şener, 2008: 260). Tekel fiyatlamasıyla elde edilen gelirle toplumsal fayda artışı sağlayacak türden mal ve hizmetlerin finansmanın sağlanması biçimde çapraz finansman toplum refahında artış sağlayacağı için tekel fiyatlamasının neden olacağı refah kaybı kısmen telefi edilmiş olacaktır.

Ortalama maliyet fiyatlamasına bakıldığında temel amacın kamu finansman ihtiyacını artırmadan toplum refahının artırılmasının amaçlandığı görülür. Ortalama maliyet fiyatlamasında kamu ekonomisi faaliyetleri içinde sunulan/üretilen malların ortalama maliyetini karşılayacak bir fiyat belirlenmesi esastır. Böylece, sunulun mal ve hizmetin maliyeti tamamen yararlananlara aktarılmış olmaktadır. Tekel fiyatlamasıyla karşılaştırıldığında kamuya gelir sağlanamadığı, ancak tekel fiyatlamaya bağlı toplumsal refah kaybının önemli ölçüde azaltıldığı ifade edilebilir.

Marjinal maliyet fiyatlaması esasen son birimi üretmenin maliyetini karşılamayı esas almakta ve işletme maliyetlerine indirgenmektedir. Kısa vadede birim üretimin değişken maliyetlerini esas aldığı için ortalama maliyetin altında belirlenmektedir. Ağırlıklı olarak atıl kapasite sorunu gözlenen doğal tekel piyasalarında uygulanması tercih edilmektedir. Bu piyasalarda üretim artışına bağlı azalan maliyet koşulları geçerlidir. Azalan maliyet koşullarından yararlanarak talebin daha fazla karşılanması yetersiz tüketime bağlı refah kaybının azaltılmasına imkan sağlamaktadır.

Marjinal maliyet fiyatlamasında sabit maliyetler dikkate alınmadığı için belirlenen ortalama maliyetin altında kalmaktadır. Diğer bir ifadeyle marjinal maliyet fiyatlaması hizmetin zararına üretilip/sunulması sonucunu doğurmaktadır. Bu durumda aradaki fark hazineden karşılanacağı için kamu finansman dengeleri üzerinde yük oluşturacaktır. Marjinal maliyet fiyatlaması ağırlıklı olarak eğitim, sağlık ve ulaştırma hizmetlerinde kullanılmaktadır. Bu hizmetlerden yararlananların maliyetlerin belli ölçüde de olsa karşılanması istemektedir. Çünkü bu hizmetler toplumsal fayda sağlama kadar bireysel fayda da sağlamaktadır. Dolayısıyla marjinal maliyet fiyatlamasıyla bireysel faydaların yararlanıcılara ödetilmesi, toplumsal faydanın da topluma yayılmasını amaçlamaktadır.

$\mathrm{Bu}$ stratejiler farklı fiyatlama modelleri ile işlerlik kazanabilmektedir. Bu modeller aşağıda açıklanmaya çalışıımıştır. 


\subsubsection{Kamusal Fiyatlama Modelleri}

Kamusal fiyatlamanın amaç ve stratejilerine uygun, kullanılan fiyatlama modellerini "yoğun dönem fiyatlaması", "iki parçalı fiyatlama", "gölge fiyatlaması", "ikinci en iyi fiyatlama" ve "fiyat farklılaştırması" olarak saymak mümkündür.

Bunlardan ilki yoğun dönem fiyatlamasıdır. Yoğun dönem fiyatlamasında amaç arz kıstı altında hizmet kalitesini en üst düzeye çıkarmak ve gelir artışı sağlamaktır. Burada talep zamanı ve talep esnekliği olmak üzere iki unsur söz konusudur. Talebin zirve yaptığı yoğun dönemlerde hizmetten yararlanmanın marjinal maliyeti artırılarak, ilave kapasite talebi zamanlar arası talep kaymasıyla karşılanabilmektedir. Talebin ne ölçüde kaydırılabileceği ve fiyat marjının ne kadar olacağı hizmet talebinin fiyat esnekliğine bağlıdır. Belirlenecek talep esnekliklerine duyarlı bir fiyat tarifesinin oluşturulması gerekecektir. Bu yönüyle yoğun dönem fiyatlaması çoklu fiyat tarifeleri şeklinde uygulanabilmektedir (Işık, 2014: 80-82).

Iki parçalı fiyatlama modeli ağırlıklı olarak ortalama maliyet fiyatlama stratejisine uygun bir fiyatlama modelidir. Sabit ve değişken maliyetlerin karşılanmasını amaçlamaktadır. Fiyatın bir parçası ile sabit maliyetlerin karşılanması amaçlanırken, diğer parçasıyla değişken maliyetlerin karşılanması amaçlanmaktadır. Ağırlıklı olarak abonelik yöntemiyle sunulan hizmetlerin fiyatlamasında kullanılmaktadır. Sabit maliyetler kapasite büyüklüğü ile orantılı olarak yararlanıcılara katılım bedeli şeklinde belirlenen fiyat üzerinden karşılanırken, değişken maliyetler marjinal maliyet fiyatlaması şeklinde karşılanmaktadır. Böylece sunulan mal veya hizmetin toplam maliyeti yararlanıcılara dağıtılarak hizmetin bütçe üzerinde yükü olabildiğince azaltılabilmektedir.

Bir diğer kamusal fiyatlama modeli de "fiyat ayrımcılığı modeli"dir. Bu modelde aynı hizmet, talep fiyat esneklikleri farklı kesimlere, farklı fiyattan arz edilmektedir. Gelire atfedilen marjinal fayda farklııkları bireylerin fiyat değişmelerine duyarlılı̆ını belirlemektedir. Gelirin marjinal faydası yüksek olan bireylerin fiyat değişmelerine duyarlılığı yüksek olduğu için küçük fiyat artışlarında taleplerini önemli ölçüde azaltabilmektedir. Bu nedenle talep fiyat esnekliği farklı tüketici kesimlerin farklı fiyattan sunulması tercih edilmektedir. Fiyat farklılaştırması talebin mümkün olduğunca en üst düzeyde karşılanması ve hizmet sunumunun bütçeye yükünü en aza indirmek amaçlanmaktadır. Bu özelliği ile ortalama maliyet fiyatlama stratejisine uygun bir fiyatlama olarak değerlendirilebilir. Ancak, bu modelde tüketicilere maliyet üzerinden değil ödeme gücü ve sağladıkları fayda üzerinden fiyatlama yapılmaktadır. Diğer bir ifadeyle fiyat ayrımcılığı modeli daha çok sosyal refahı en üst düzeye çıkarmak amacıyla kullanılmaktadır. Özellikle dar gelirlilerin yoğun olarak kullandıkları mal ve hizmetlere ilişkin bu modelinin kullanılması tercih edilmektedir. Örneğin, toplu ulaşım hizmetlerinden öğrenci ve yaşılar gibi sosyal açıdan dezavantajlı gurupların düşük fiyattan yararlanmalarına imkan sağlanırken, aynı hizmet diğer kesimlere ise daha yüksek fiyattan sunulmaktadır.

Kaynak tahsisinde etkinlik arayışına yönelen karar alıcılar "ikinci en iyi fiyatlama modeli"ne yönelebilmektedir. İkinci en iyi fiyatlama modeli, özellikle, marjinal 
maliyetin belirlenmesinde zorluk yaşanan ikame mallar piyasasında kullanılmaktadır. Bilindiği gibi ikame mallar arasında oluşturulacak fiyat farklılıkları tercih kaymalarına bağlı etkinlik kayıplarının oluşmasına neden olmaktadır. Etkinlik kayıplarının önlenmesi amacıyla ikame malların birim fiyatlarının aynı veya tercih sapmasına imkan vermeyecek ölçüde yakın belirlenmesi tercih edilmektedir. Bu tercihe bağlı fiyatlama ikinci en iyi fiyatlama modeli olarak ifade edilmektedir. İkame edilebilir akaryakıt türevi ürün piyasasında kullanılan fiyatlama ikinci en iyi fiyatlamaya örnek olarak verilebilir. ikame mallar arası fiyat kaynaklı tercih sapmalarını en aza indirmek amacıyla LPG ve benzin fiyatlarının neredeyse aynı seviyeye getirilmiş olması LPG'li ve benzinli araçlar arasındaki tercihi sadece araçların teknik üstünlüklerine indirgemektedir. Diğer bir ifadeyle yakıt fiyat farklılığı ürün talebini etkilemeyeceği için arz talep dengesini sadece ürünün teknik özelliklerine indirgenmiş olacaktır.

Kamusal özellik taşıyan malların her zaman için fayda maliyet ilişkisini kurmak mümkün olmamaktadır. Piyasanın rekabet şartlarını yerine getirmesinin mümkün olmadığı veya kaynak kullanım etkinliğinin kaybolduğu alanlarda piyasa fiyatları gerçek maliyetleri gösterme fonksiyonunu yerine getiremez (Şataf, 2014: 58). Örneğin, yüksek işsizlik ortamında kamu tarafından istihdam edilen çalışanların alternatif maliyeti sıfır olacaktır. Bu gibi durumlarda gölge fiyatlandırması modelinden yararlanılmaktadır. Diğer bir ifadeyle gölge fiyatlaması; bir kamu hizmetinin maliyetinin ve faydasının eğer bu hizmet özel sektör tarafından sunulması durumunda, karşılığının piyasa fiyatı cinsinden ölçülmesidir (Şener, 2016: 300-308). Böylece, bir kamu hizmetinin alternatif sosyal fayda ve sosyal maliyetinin piyasa fiyatları yönünden hesaplanması bu yöntemle kolaylaşmaktadır.

\section{Azerbaycan Ekonomisinin Genel Yapısı ve Fiyat yapısının İşleyişi}

\subsection{Azerbaycan Ekonomisinin Yapısı}

Azerbaycan ekonomisinin yapısı üç dönem içinde ele alınmıştır. illk dönem Bağımsızlık sonrası piyasa ekonomisine geçiş sürecini, ikinci dönem 2015 yılında yaşanan ekonomik kriz dönemi ve üçüncüsü ise 2017 yılı sonrası dönemdir.

Azerbaycan Cumhuriyeti 1991'de bağımsızlığını yeniden kazandıktan sonra egemenlik haklarını ekonomik alanda kullanmaya ve bağımsı politika izlemeye başlamıştır. Bu politikaların esas istikameti kapitalist bir ekonomik sistem kurma yönünde olmuştur. Bu çerçevede, özel mülkiyeti esas alan piyasa ekonomisine geçiş ve dünya ekonomisine uyum sağlama amaçlanmıştır.

$\mathrm{Bu}$ amaç doğrultusunda gelişmeler iki aşamada incelenebilir. Illk aşama 19911995 yıllarını kapsayan ekonomik kaos veya durgunluk dönemidir. Bu aşama, sistem değişiminin beraberinde getirdiği belirsizlikler içerisinde geçmiştir. Bu süreçte devlet otoritesinin tesisi ve mülkiyet haklarının tanımlanması çalışmaları yürütülmüştür.

İkinci aşama ise, 1996 yılından bu yana devam eden makroekonomik istikrar ve dinamik ekonomik gelişme aşamasıdır. 1995'den sonra ekonomide esas amaçlardan 
biri ülke petrolünün dünya pazarları ile buluşturulmasıydı. Bu maksatla 1996 yılında Bakü - Novorossiysk, 1999 yılında ise Bakü - Supsa ihraç boru hatları kullanıma girdi, bu arada bir de Bakü-Tiflis-Ceyhan ana ihracat petrol boru hattının inşası hakkında kontrat imzalanmış ve bu hatlardan petrol ihracatı başlatılmıştır. Bu süreçte petrol ve gaz sektörü, ekonominin diğer sektörlerinin gelişmesinde anahtar rol oynamıştır.

1996 yılından sonraki gelişmelerle birlikte makroekonomik istikrarın ve sürdürülebilir ekonomik büyümenin sağlanması amacıyla ekonominin tüm sektörlerinde reformlar başlatılmış ve nüfusun yaşam standartlarının iyileştirilmesine yönelik ciddi adımlar atılmıştır.

Girişimciliğin geliştirilmesi, olumlu iş ve yatırım ortamı yaratılması ve petrol dışı sektörel gelişmenin sağlanması amacıyla, yerli ve yabancı yatırımların artırılması iktisat politikasının tipik özelliklerinden biri olmuştur. Uygulanan önlemlerin bir sonucu olarak, Azerbaycan'da girişimciliğin desteklenmesi ülkenin sosyo-ekonomik kalkınmasında özel sektörün rolünü arttırmıştır.

Ekonomideki özel mülkiyet haklarının korunması amacıyla yapılan çalışmalar, sürdürülebilir ekonomik kalkınmaya olumlu katkı sağlamıştır. Özelleştirme başladığında, özel sektörün GSYiH içindeki payı \%10 oranındayken, günümüzde bu oran \%83'e ulaşmıştır.

Azerbaycan Cumhuriyeti'nin, bağımsızlığını kazandıktan sonra, başlıca dış ekonomik politikalarından biri de uluslararası finansal kredi ve ekonomik kurumlarla ilişkiler kurmak olmuştur. Azerbaycan 1992'de Uluslararası Para Fonu, Dünya Bankası, Avrupa Yeniden Yapılanma ve Kalkınma Bankası, İslam Kalkınma Bankası ve 1999'da Asya Kalkınma Bankası da dahil olmak üzere neredeyse tüm etkin uluslararası örgütlere katıldı. Böylece uluslararası ekonomik işbirliklerine taraf bir aktör haline gelerek, uluslararası ekonomik gelişmeleri daha yakından takip edip, uyum sağlama imkanı elde etmiş oldu.

2003-2013 senelerini kapsayan 10 yıllık devirde Azerbaycan'da GSYiH oranı 3,4 kat artarken, petrol dışı sektörlerdeki büyüme ise 2,7 kat artış göstermiştir. Petrol ihracat alt yapısının güçlendirilmesi, ülkenin stratejik döviz rezervlerini 30 kat artırarak, 50 milyar dolara ulaşmasını sağlamıştır. İzlenen ekonomik politikalar 1.2 milyon iş yeri açılmasına imkan sağlayarak, işsizliğin \% 5,2 seviyesine indirilmesinde etkili olmuştur. Bu gelişmelerin sonucunda kişi başına düşen gelir 6,1 kat artarken, yoksulluk \% 6'ya kadar inmiş ve nüfusun refah düzeyini önemli ölçüde artırmıştır ${ }^{1}$.

Tüm bu olumlu gelişmelerin yanında dünya ekonomisiyle önemli ölçüde entegre olan Azerbaycan ekonomisi, gerek iç ve gerekse dış ekonomik gelişmelerden etkilenmektedir. Özellikle petrol ihracatına dayanan yapısıyla dünya enerji piyasasındaki gelişmelerden doğrudan etkilenmektedir. Bunun en önemli göstergesi 2015 yılı ekonomik gelişmelerinden izlemek mümkündür.

\footnotetext{
1 'Azerbaycan Ekonomisi Hakkında Genel Bilgiler', http://azerbaijan.az/portal/Economy/General/ generallnfo_01_a.html Erişim tarihi: 27.09.2017.
} 
2015 yılındaki küresel ekonomideki belirsizlik, Çin'in ekonomik büyümesindeki yavaşlama ve küresel borsalardaki dalgalanmalar, küresel ekonomik büyümeyi olumsuz bir şekilde etkiledi. Mantıksal bir sonuç olarak, dünya pazarındaki petrol ve petrol ürünlerinin fiyatlarındaki düşüş 2014 yılından sonra hızlanmaya başlamış ve varil fiyatı 36 dolar ile son yedi yılın en düşük seviyesine gelmiştir. Bu durum Azerbaycan da dahil olmak üzere, bir çok petrol üreticisi ülkede etkisini göstermiş ve önemli devalüasyonların yapılmasına neden olmuştur. Bunun sonucu ülkelerin GSYH artışları sınırlı kalmıştır. Örneğin, Azerbaycan ekonomisi açısından, 2011 yılı dikkate alınmadığında, 1995 senesinden sonra 2015 yılında \% 1.1 ile en düşük büyüme oranı yaşanmıştır.

Şekil 5: Son 10 Yılda Bütçe Gelirlerinin Büyüme Çizelgesi

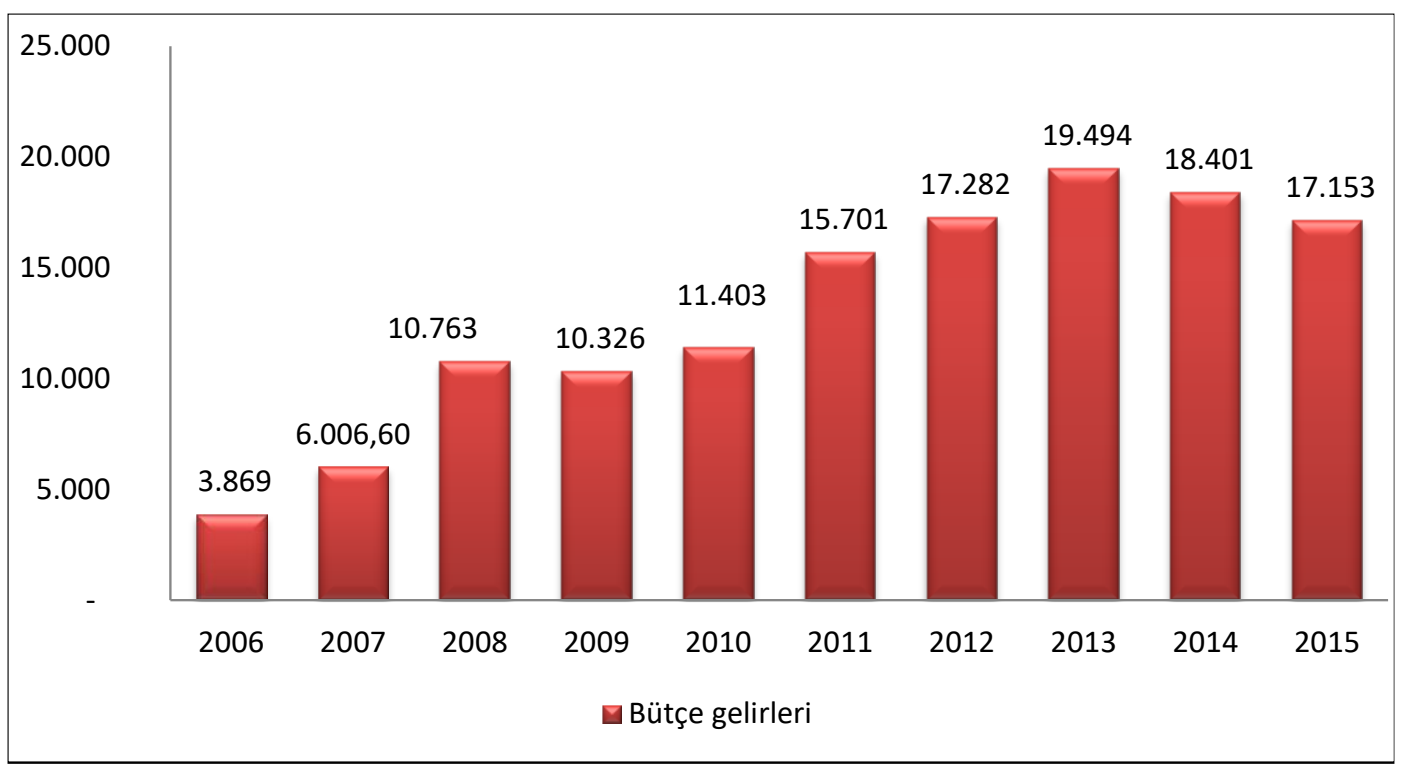

Bu sonucu ortaya çıkaran ana neden kamu mali yapısının ve ekonomik üretimin uluslararası petrol fiyatlarına bağımlı olmasıdır. Azerbaycan bütçe gelirlerinin büyük bir kısmı ham petrolün satışı gelirlerinden oluşmaktadır. Şekil 5, son on yılda bütçe gelirlerin büyüme eğilimini göstermektedir. 2009, 2014 ve 2015 yıllarında bütçe gelirlerinde azalma gözlemlenmektedir. Bunun esas nedeni uluslararsı piyasalardaki petrol fiyatlarınını düşmesidir. 2015 yılının bütçe gelirleri 19.438 milyon manat olarak öngörülürken, 17.153 milyon manat olarak gerçekleşti ve bu geçen yılın aynı dönemine göre yaklaşık 1.2 milyar daha az gerçekleşmiştir².

Azerbaycan ekonomisinin uluslararası petrol fiyatlarındaki gelişmelere bağlı yapısı kontrol edilebilirliği zor olan istikrarsız bir karaktere sahip olup, bu özelliği petrol dışı sektörlerde üretim altyapısının kurulup geliştirilmesini zorunlu kılmaktadır. Bunun başarılabilmesi mal ve para (finans) piyasaları arasındaki ilişkinin serbest piyasa

2 '2015 Yılında Azerbaycan Ekonomisi - rapor', http://caspianbarrel.org/az/2016/02/2015-ci-il-azrbaycan-iqtisadiyyatinin-neftd-n-asililiq-numun-si-kimi-hesabat/ Erişim tarihi: 25.09.2017. 
ekonomisi esaslarına uygun olarak kurulmasını ve geliştirilmesini zorunlu kılmaktadır. $\mathrm{Bu}$ çerçevede rekabet koşullarını işler kılacak bağımsıuz düzenleyici denetleyici kurumsal yapıların oluşturulması gerekmektedir.

Bu gerekliliklerin farkında olan Azerbaycan ekonomi yönetimi mal ve para piyasaları arasındaki ilişkilerin serbest piyasa ekonomisi temelinde kurulmasını sağlamak ve fiyat oluşumunun piyasa işleyişine yaklaşmasını temin amacıyla 2016 yılında yeni bir yapılanma içine girmiştir. Mal piyasalarında fiyat oluşumunu etkileyen tarif şurasına benzer bir yapı, "Maliye Pazarlarına Kontrol Palatası"3 adıyla para piyasaları için de oluşturulmuştur.

Bu yapı, "Bankalar", "Banka dışı kredi kuruluşları", "Kredi sendikaları", "Posta", "Sigortacılık faaliyeti", "Zorunlu sigorta”, "Menkul kıymetler piyasası", "Yatırım fonları", "Para Birimi Yönetmeliği", "Mevduat Sigortası" ve diğer kurumların kanunlarına göre kurulmuş ve bu kurumların finansal piyasalarını denetleme ve izleme yetkilerine sahiptir. Bu yetki çerçevesinde para piyasalarının yasal ve idari işleyişi düzenlemeyecek mevzuatı geliştirmek, finansal kurumların kuruluş izinlerini vermek, faaliyetlerini denetlemek, kara para aklama faaliyetlerini engellemek ve finansal piyasalarda doğru ve simetrik bilgi akışını sağlamak gibi görevlere sahiptir.

"Maliye Pazarlarına Kontrol Palatası" finans piyasalarını ve finansal ürünlerin fiyat oluşumunu piyasa odaklı oluşumuna katkı sağlamaktadır. Finans piyasalarında sağlıklı fiyat oluşumunun mal piyasalarına yansıması da olumlu olacaktır. Bu yönüyle mal piyasalarında fiyat oluşumunu düzenleyen tarif şurasının faaliyetelerini tamamlayıcı bir niteliğe sahip olduğu söylenebilir. Bu niteliği rekabet kurumunun sağlıklı işleyişini sağlayacak yasal atyapı ve uygulamalarla güçlendirilmiş olmayacaktır.

\subsection{Tarif Şurası'nın Yapısı ve İşleyişi}

Mal piyasaalarında fiyat oluşumunun düzenlenmesi amacıyla oluşturulan Tarif şurası benzeri yapıların geçiş ekonomilerinin tamamnında var olduğu gözlenmektedir. Tarif Şurası, bir yönüyle fiyatın piyasa ekonomisi koşullarında oluşmasına imkan sağlarken bir yönüyle de rekabet koşullarından uzaklaşmasına neden olmaktadır. Fiyat oluşumu üzerindeki etkisini daha iyi açıklamak amacıyla Tarif Şurası'nın yapısı ve işleyişi aşağıda ele laınmıştır.

\subsubsection{Tarif Şurası'nın Yapısı}

Ekonomik birim olarak devlet topluma sunduğu mal ve hizmetlerin finansmanına katılımını sağlamayı amaçlamaktadır. Kapitalist ekonomik sistem açısından oldukça doğru bir yaklaşımdır. Ancak, yukarıda da açıklandığı gibi devlet bu konuda kamusal yarar kısıtı altında hareket ettiği için fiyatı piyasa koşullarında belirleyememektedir. Bu noktada kendince fiyat oluşum mekanizmaları kurum işletebilmektedir. Azerbaycan Cumhuriyeti de bu konuda kendince bir sistem kurmuş ve işletmektedir. Azerbaycan'da kamusal

\footnotetext{
${ }^{3}$ Bu yapılanma hakkında ayrıntılı bilgi için https://fimsa.az/ sayfasından yararlanılabilir.
} 
fiyatlama "Tarif Şurası" olarak isimlendirilen yapı tarafından belirlenmektedir. 31 Mayıs 2005 tarih ve 242 sayılı Cumhurbaşkanlığı fermanıyla Tarif Şurasının kurulmasına karar verilmiş ve 26 Aralık 2005 tarihinde kurulmuştur.

Tarif Şurası ülkede mal ve hizmet fiyatların ve tahsili için gerekli hususların belirlenmesi amacıyla kurulmuştur. Tarif şurasının yapısı içinde Maliye, Vergiler, Adalet, Enerji, Ulaşım, İletişim, Ziraat, Sağlık, Eğitim, Çalışma Bakanlıkları ve Devlet Gümrük ve Mimari Komite temsilcileri yer almaktadır. Ekonomi Bakanı Şura'ya başkanlık yapmaktadır. Tarif Şurası çalışmalarını bölgesel ve uluslararası kurumlar ile işbirliği içinde yürütmektedir. Bu bağlamda Şura fiyat tespit çalışmalarında Azerbaycan Anayasasını, kanunlarını, Cumhurbaşkanı'nın imzaladığı fermanları, Bakanlar Kurulu Kararlarını, Azerbaycan'ın taraf olduğu uluslararası anlaşmaları temel almakla yükümlü kılınmıştır.

Günümüzde Tarif Şurası devlet (yasal) ve doğal tekele konu mal ve hizmetler ile özel mal ve hizmetlerin fiyat oluşum sürecini yönetmekte ve işletmektedir ${ }^{4}$. Bu çerçevede Şuraya Tablo 1'de sayılan 41 kalem mal için fiyat belirleme yetkisi verilmiştir. Cumhurbaşkanı bu listeye mal ve hizmetleri ilave etmek ve listeden çıkarma yetkisine sahiptir.

Şura, fiyat tespit sürecinde kendi çalışma gruplarını ve komisyonlarını oluşturmak, izleme yapmak ve çalışmalarına uzmanlar çağırmak için merkezi ve yerel yürütme organları, ekonomik kuruluşlar, yerel öz denetim organları ve kamu kuruluşlarıyla faaliyetlerini yürütme yetkisine sahiptir.

Tablo 1: Tarif Şurasının Fiyatını Belirleyeceği Mal ve Hizmetler

\begin{tabular}{|c|l|c|l|}
\hline 1 & Elektrik enerjisi & 22 & Isı enerjisi \\
\hline 2 & $\begin{array}{l}\text { Ham petrol ve temel yağ rafine } \\
\text { ürünleri }\end{array}$ & 23 & Veterinerlik alanındaki temel hizmetler \\
\hline 3 & Doğalgaz. & 24 & Devlete ait eğitim hizmetleri \\
\hline 4 & Sıvı gaz (toptan satış & 25 & Iletişim hizmetleri \\
\hline 5 & $\begin{array}{l}\text { Devlet Konut Fonu konutlarından } \\
\text { sosyal konut veya kira sözleşmelerinin } \\
\text { kullanımı (kiralanması), bu alanların } \\
\text { bakım ve onarımı için ücretler. }\end{array}$ & 26 & $\begin{array}{l}\text { Devlet Gümrük Komitesi siciline bankalar } \\
\text { ve diğer kredi kuruluşlarının kaydedilmesi }\end{array}$ \\
\hline 6 & $\begin{array}{l}\text { Gayrimenkul ve arsa parsellerinin } \\
\text { kadastrosu, tescili ve teknik envanteri } \\
\text { ile bağlı hizmetler }\end{array}$ & 27 & $\begin{array}{l}\text { Doğalgazın boru hatları vasıtasıyla } \\
\text { taşınması, depolanması ve dağıtımı } \\
\text { hizmetleri }\end{array}$ \\
\hline 7 & İ̧me suyu ve teknik su & 28 & \begin{tabular}{l} 
Devlete ait laboratuar hizmetleri \\
\hline
\end{tabular}
\end{tabular}

\footnotetext{
4 'Tarif (fiyat) Şurası', http://www.tariffcouncil.gov.az/?/az/content/44/, Erişim tarihi: 17.08.2017.
} 
Selen, U. \& O. Samadzade (2018). "Azerbaycan Ekonomisinde Fiyat Oluşumunda Tarif Şurasının Rolü", International Journal of Public Finance, Vol.3, No.1, pp. 83-106.

\begin{tabular}{|c|c|c|c|}
\hline 8 & $\begin{array}{l}\text { Kamu kuruluşlarında tıbbi bakım, } \\
\text { muayene, tedavi ve sağlık hizmetleri }\end{array}$ & 29 & $\begin{array}{l}\text { Her türlü taşıma hizmetleri: Demiryolları } \\
\text { ve deniz taşımacılığı ile transit yüklerin } \\
\text { taşınması hizmetleri }\end{array}$ \\
\hline 9 & $\begin{array}{l}\text { Doğal kaynaklar alanında temel } \\
\text { hizmetler }\end{array}$ & 30 & $\begin{array}{l}\text { Ana boru hatları vasıtasıyla petrol ve } \\
\text { petrol ürünlerinin taşınması hizmetleri }\end{array}$ \\
\hline 10 & Hidrometeoroloji hizmetleri & 31 & Karantina önlemleri uygulama hizmetleri \\
\hline 11 & Isı kaynağı & 32 & Kamu hizmetleri test sınavlarına katılmak \\
\hline 12 & Ormancılık alanında temel hizmetler & 33 & İnşaat, mimarlık ve kentsel hizmetler \\
\hline 13 & $\begin{array}{l}\text { Zararlı madde taşıma ve } \\
\text { dezenfeksiyon hizmetleri }\end{array}$ & 34 & $\begin{array}{l}\text { Arazi ıslahı ve su ekonomisi alanındaki } \\
\text { başlıca hizmetler }\end{array}$ \\
\hline 14 & $\begin{array}{l}\text { Tıbbi ürünler uzmanlığı, devlete kayıtlı } \\
\text { ilaçların fiyatları }\end{array}$ & 35 & $\begin{array}{l}\text { Devlete ait kamu hizmet sektöründeki } \\
\text { temel hizmetler }\end{array}$ \\
\hline 15 & $\begin{array}{l}\text { Topraklara biyolojik, biyokimyasal ve } \\
\text { kimyasal hizmetler }\end{array}$ & 36 & $\begin{array}{l}\text { Avcıların avlanma (su ve orman avcılığı) } \\
\text { hizmetleri }\end{array}$ \\
\hline 16 & Özel iletişim hizmetleri & 37 & Devlet Trafik Polisi İdaresi hizmetleri \\
\hline 17 & Kamu yol yapım ve bakım hizmetleri & 38 & Gemiler için teknik muayene hizmetleri \\
\hline 18 & $\begin{array}{l}\text { Devlete ait ve taşınır emlak fiyatlarının } \\
\text { belirlenmesi }\end{array}$ & 39 & $\begin{array}{l}\text { Devlete mahsus protez-ortopedik } \\
\text { rehabilitasyon merkezi hizmetleri }\end{array}$ \\
\hline 19 & $\begin{array}{l}\text { Merkezi ve yerel idare makamları ve } \\
\text { belediyelerin sahip olduğu spor } \\
\text { tesislerinde düzenlenen spor } \\
\text { müsabakalarına giriş ücretleri, bu tür } \\
\text { imkânları kullanan vatandaşlar için } \\
\text { üyelik fiyatları, bütçesel kaynaklardan } \\
\text { finanse edilen merkezi kuruluşlar } \\
\text { tarafından sağlanan hizmetler }\end{array}$ & 40 & $\begin{array}{l}\text { Azerbaycan Cumhuriyeti gümrük } \\
\text { bölgelerine ithal edilen ve bu bölgede } \\
\text { satın alınan gümrük antrepoları hariç } \\
\text { geçici depolama ve depolama hizmetleri. }\end{array}$ \\
\hline 20 & $\begin{array}{l}\text { Azerbaycan Cumhuriyeti Devlet } \\
\text { Denizcilik İdaresi hizmetleri. }\end{array}$ & \multirow[t]{2}{*}{41} & \multirow{2}{*}{$\begin{array}{l}\text { İnceleme ve diğer kontroller kapsamında } \\
\text { muayene kuruluşları tarafından bireylerin } \\
\text { ve tüzel kişilerin malların (ürünlerin) } \\
\text { müsadere edilmesi, nakli, bakımı veya } \\
\text { yok edilmesi ile ilgili hizmetler }\end{array}$} \\
\hline 21 & $\begin{array}{l}\text { Apartmanlar dahil olmak üzere } \\
\text { konutların elektrik, gaz ve su temini } \\
\text { hizmetleri. }\end{array}$ & & \\
\hline
\end{tabular}

Kaynak: Azerbaycan Cumhuriyeti Bakanlar Kurulu, 'Tarifleri Devlet Tarafından Düzenlenen Malların (İşlerin, Hizmetlerin) listesinin onaylanması üzerine karar', http://e-qanun.az/framework/11342 Erişim tarihi: 21.08.2017.

\subsubsection{Tarif Şurası'nın Karar Alma Süreci}

Tarif Şurası, sağlık sektörünün niteliğinden hareketle, fiyat belirlemesinde farklı yaklaşım içinde hareket etmektedir. Bu yaklaşım farklılıklarını aşağıdaki gibi ortaya koymam mümkündür. 


\subsubsection{Sağlık Sektörü Dışındaki Mal ve Hizmetlerin Fiyatlandırılması}

Tablo 1'de sayılan mal ve hizmetlerin fiyatları Cumhurbaşkanı, Bakanlar Kurulunun ve/veya mal ve hizmetin sunumundan sorumlu kurumların talebi doğrultusunda değiştirilebilmektedir.

Talep üzerine Tarif Şurası, görev tanımı içindeki mal ve hizmetlerin fiyatlarını ilgili kurum, kuruluş ve şahıslarla yaptığı istişareler sonucunda belirlemektedir. Bu süreçte, Bakanlar Kurulu kararı ile kontrol ve denetim kurumları her sene 1 Mart'a kadar mal ve hizmetin sunumundan sorumlu kurumlardan (öznelerden) topladığı raporları Şura'ya sunar.

Fiyatın belirlenebilmesi için Şura'ya sunulan raporlarda yer alan belgelerde bir eksiklik olduğu takdirde, öznelere 5 gün içerisinde yazılı bildirimde bulunmak kaydıyla, bildirimi takiben 5 gün içinde eksikliği giderebilirler. Mal veya hizmetlerin özdeğerini belirlemeye yönelik bilgi ve belgeler tamamlandıktan sonra özdeğere ilave edilecek gider kalemleri, vergiler, gelir ve diğer unsurlar net biçimde belirlenerek bir fiyat teklifi oluşturulur. Oluşturulan fiyat teklifleri Şura'ya sunulur. Sunulan teklifler Şura toplantısında ele alınarak fiyat teklifine son şekli verilerek Şura kararına bağlanır. Şura kararını oluştururken;

1) Objektif nedenlerden dolayı malların veya hizmetlerin üretim maliyetlerinin artmasını,

2) Mal ve hizmetin sunumundan sorumlu kurum raporlarının taleplerle uyumlu olmasını,

3) Dünya piyasalarında fiyatların keskin değişmesi ve ülkede oluşan sosyal ve ekonomik koşulları dikkate alır.

Bunlardan başka zorunlu hallerde Şura'nın girişimiyle de fiyatlarda değişiklik yapılabilir. Bu çerçevede oluşturulan Şura kararı Cumhurbaşkanı'nın onayına sunulur ${ }^{5}$. Şuranın belirlediği fiyatlara ilişkin son karar Cumhurbaşkanı tarafından verilmektedir. Cumhurbaşkanı'nın, Şuranın belirlediği fiyatları kontrol ederek değişiklik yapma veya alınan kararı veto etme yetkisi vardır. Örneğin, 2015 yılının Ocak ayında benzin fiyatının artırılması yönündeki Şura kararı Cumhurbaşkanı tarafından uygun bulunmayarak veto edilmiştir ${ }^{6}$. Ancak, 14 Temmuz 2017 tarihinde Devlet Petrol Şirketi'nin talebi üzerine Tarif Şurası bu konuyu yeniden ele almış ve fiyatın yükselmesi yönünde karar vermiştir. Bu karar Cumhurbaşkanı tarafından da onaylanmıştır.

\footnotetext{
${ }^{5}$ Azerbaycan Cumhuriyeti Bakanlar Kurulu, 'Devlet düzenlemesine alınan fiyatların oluşturulması ve uygulanmasına ilişkin devlet kontrolü kuralları', http://e-qanun.az/framework/14583 Erişim tarihi: 25.08.2017.

6 Azerbaycan Cumhuriyeti Bakanlar Kurulu, 'Cumhurbaşkanı IIham Aliyev, Tarif Şurası'nın benzin fiyatlarını artırma kararını iptal etti', https://news.milli.az/politics/318991.html Erişim tarihi: 19.08.2017.
} 


\subsubsection{Devlete Kayıtı Tıbbi Ürünlerin ve Ilaçların Fiyatlandırılması}

Bu kategoride fiyat oluşumunun diğer alanlardan farklı olduğunu belirtmek gerekir. Tarif Şurası tıbbi ürünlerin ve kayıtlı ilaçların fiyat oluşumunda Türkiye İlaç ve Tıbbi Cihaz Kurumu'nu kendine baz alıyor ve ayni yöntemleri kullanmaktadır. Bu yöntem Azerbaycan Bakanlar Kurulu'nun 3 Haziran 2015 tarihinde imzaladığı 209 numaralı kararla onaylanmıştır. Karar alındıktan sonra Tarif Şurası Sağlık Bakanlığı tarafından kayda alınmış tıbbi ürünlerin ve ilaçların fiyat oluşumu prosedürüne başlamıştır.

Tıbbi ürün ve ilaçlar için temel fiyat ve satış fiyatı olmak üzer iki ana fiyat belirlenmektedir. Temel fiyat, ilgili ürün ve ilacın ticari ambalajı dikkate alınarak, farklı ülkelerdeki toptan satış fiyatı esas alınarak belirlenmektedir. Temel fiyatı hesaplanma metodu Şura tarafından belirlenir. Buna göre Şura, her yıl için beş referans ülke belirler. Bir ülkenin referans ülke alınabilmesi için bilgi kaynaklarına erişim imkanlarının fazla olması gereklidir. Ilaç fiyatlarının belirlenmesinde kullanılan bu bilgi kaynakları Şura'nın resmi internet sitesinde yayınlanmaktadır.

Bilgi kaynakları Referans ülke değişikliğinin, cari yılın 31 Ekim tarihine kadar, yapılarak ilan edilmesi gerekmektedir. Bu tarihe kadar değişiklik yapılmamış ise cari referans ülke verileri gelecek yıla ilişkin fiyat tespitlerinde de dikkate alınır.

Tıbbi ürün ve ilaçların satış fiyatı toptan veya perakende satışı dikkate alınarak belirlenir. Tıbbi ürüne yönelik toptan satış fiyatı referans fiyata belli bir kar marjı ilave edilerek belirlenir. İlacın ülke çapında eczaneye toptan satış fiyatı, ABD Doları karşııı̆ı ulusal para cinsinden kontrol markasının fiyatı esas alınarak taban fiyat üzerinden hesaplanır. Resmi döviz kurlarındaki değişikli dolayısıyla \%5'den fazla fark oluşması halinde Şura fiyatları olağanüstü bir sırada yeniden değerlendirebilir.

Perakende satış fiyatı ise KDV'siz toptan satış fiyatına eczaneler için öngörülen uygun bir kar marjı eklenerek belirlenir. Eklenecek kar marjları eşyanın toptan satış fiyatı baz alınarak Tablo 2'deki oranlarda belirlenir.

Tablo 2: Perakende İlaç Satış Fiyatlarının Oluşumunda Kar Oranları

\begin{tabular}{|l|c|l|c|}
\hline \multicolumn{1}{|c|}{ Fiyat Aralığı } & Kar Oranı \% & \multicolumn{1}{|c|}{ Fiyat Aralığı } & Kar Oranı\% \\
\hline 5 manata kadar olan ilaçlar & 0,20 & $\begin{array}{l}50-100 \text { manat } \\
\text { aralığında olan ilaclar }\end{array}$ & 0,07 \\
\hline $\begin{array}{l}\text { 5-20 manat aralığında olan } \\
\text { ilaçlar }\end{array}$ & 0,17 & 100 Manat ve Üzeri & 0,03 \\
\hline $\begin{array}{l}\text { 20-50 manat aralığında olan } \\
\text { ilaclar }\end{array}$ & 0,13 & & \\
\hline
\end{tabular}


Fiyatlar, ilaçların ve ticari ambalajların her bir dozu için ayrı ayrı belirlenmektedir. Üçer aylık süreler itibariyle fiyatların güncellenmesi hususu değerlendirilmektedir. Şura tarafından belirlenen fiyatlar ve geçerlilik süresi, iki işi günü içinde, Şura'nın resmi internet sitesinde ilan edilir. Şura tarafından onaylanan fiyatlar, Azerbaycan Cumhuriyeti Sağlık Bakanlığı tarafından kayda alınan ilaç listesinde güncellenmektedir.

Bunlardan başka halk sağlığı açısından büyük öneme sahip olan, ancak ülkede üretilmeyen veya ithal edilmeyen doktor reçetesiz ilaçların temel fiyatları, Şura tarafından belirlenen özel koşullara bağlı olarak belirlenir.

\section{Piyasa Ekonomisinin Genel Özellikleri Açısından Azerbaycan Ekonomisinde Fiyat Oluşumunun Değerlendirilmesi}

Dünya ekonomisi 1989 yılında radikal bir değişime sahne olmuştur. 1989 yılında kapitalist ve sosyalist ekonomik sistemlerin adeta fiziki sınırı temsil eden ve Berlin özelinde Almanya'yı ikiye bölen Berlin duvarı yıkılmıştır. Berlin duvarının yıkılmasıyla ve 1991 yılında Sovyet Sosyalist Cumhuriyet Birliği'nin çözülmesiyle 73 yıllık Sovyet düzeni sona ermiştir. Sovyet Sosyalist Cumhuriyetler Birliği'ne bağlı çok sayıda ülke siyasal bağımsızlığını kazanmıştır. Siyasal bağımsızlığını ilan eden bu ülkeler, merkezi planlı ekonomik modelden piyasa ekonomisi modeline geçişi gerçekleştirmişlerdir. Bu ülkelerin piyasa ekonomisi modeline geçiş süreci dünya ekonomisini yeniden şekillendirirken literatüre 'Geçiş Ekonomileri' kavramının girmesine neden olmuştur.

Geçiş ekonomileri olarak tanımlanan ülke grubu içinde, 1991 yılında bağımsızlığını ilan eden, Azerbaycan da yer almaktadır. Bu süreçte Azerbaycan planlı ekonomi modelini terk ederek, ekonomik sistemini piyasa ekonomisi esaslarına göre şekillendirmeye başlamıştır. Bu çerçevede devlet mülkiyetinden farklı mülkiyet biçimlerine geçiş ve dünya ekonomisine entegrasyon çalışmalarına yönelmiştir. Büyük zorluklar içeren geçiş süreci 90'lı yılların ortalarında belli ölçüde tamamlanabilmiştir. 1996 yılında Azerbaycan Cumhuriyeti'nin petrol sektörüne tümüyle sahiplenmesi ile birlikte, petrol gelirleri üzerinde tasarrufta bulunma hakkı kazanmış ve bu da ekonomik kalkınma sürecine olumlu yansımıştır. Özellikle makroekonomik anlamda 2010'lu yıllara kadar güzel gelişmelerden söz edilebilir.

Ancak, tüm ekonomik sistemin neredeyse tümünün petrol sektöründeki gelişmelere bağlanmış olması, genel ekonomik dengeyi petrol sektöründe yaşanan tüm gelişmelere duyarlı hale getirmiştir. Petrol dışı sektörlerde piyasa ekonomisi gereklerinin karşılanamaması ve kaynakların tüm sektörlere dengeli dağılımının sağlanamamış olması devletin politika belirleme ve uygulama inisiyatifinin yetersiz olduğu biçiminde yorumlanabilir. Son dönemlerde özellikle Afrika ülkelerinin ve arz esnekliği düşük olan doğal kaynak üreticisi ülkelerin ekonomik istikrarsızlıklarının devlet kapasitesinin güçlendirilmesi yoluyla aşılabileceği değerlendirilmektedir. Dünya Bankası ve diğer uluslararası mali kuruluşların, bu ülkelerin politika belirleme ve uygulama 
inisiyatiflerinin güçlendirilmesine yönelik devlet inşa sürecinin tamamlanması gerekliliğine vurgu yaptığı gözlenmektedir (Ottervik, Mattias, 2013: 25; Besleyy and Perssonz, 2009: 38; Cingolani, 2013: 72).

Azebaycan ekonomisinde, piyasa ekonomisinin en önemli unsuru olan fiyat mekanizmasının kurulması adına önemli çalışmalar gerçekleştirilmiştir. Bu çerçevede 2005 yılında Tarif Şurası oluşturulmuştur. Şura, Bakanlar Kurulu tarafından belirlenen listede yer alan 41 kalem mal için fiyat belirleme yetkisine sahiptir. Liste kapsamı eşyaların niteliğine bakıldığında bunların doğal ve yasal tekele konu mallar ile bazı özel mallar olduğu görülmektedir. Doğal tekele konu malların bu listede bulunması piyasa etkinliğinin sağlanması açısından merkezi olarak belirlenmesi doğru bir uygulama olarak değerlendirilebilir. Ancak, yasal tekel ve özel mallarla ilgili merkezi fiyat belirlemesi piyasa ekonomisinin gereklerine uygun düşmemektedir. Yukarıda belirtildiği gibi serbest piyasada fiyat ekonomik kararların verilmesinde en önemli gösterge olup, arz ve talebin pazarlık güçlerine bağlı olarak belirlenmek zorundadır. Piyasa ekonomisinin bu gerekliliğinin karşılanması için, piyasa kurallarının hakim kılınması açısından yapılması gereken işlerin olduğu söylenebilir. Tarif şurası uygulamasına bakıldığında bireylerin fiyat oluşum sürecine sınırlı da olsa katılımına izin verildiği söylenebilir. Şöyle ki, bireyler ve firmalar ile üretici pozisyonundaki devlet kurumları bir ürün veya hizmetin fiyat değişim talebinde bulunabilmektedir.

Az gelişmiş ekonomilerin genel özelliği GSYH düzeyinin kolay artırılamamasıdır. Azerbaycan ekonomisi de bilgi ve teknolojiyi de içerecek düzeyde yeterli sermaye birikimine sahip olmaması, sektörlerin çeşitlenmemiş ve derinleşmemiş olması yönlerinden gelişmekte olan ekonomi özelliği taşımaktadır. GSYH düzeyinin düşüklüğü vergi kapasitesinin de düşük kalmasına neden olduğu için kamu finansmanın sağlanmasında kamusal fiyatlama uygulamalarından yararlanmak zorunda kalmaktadır. Bu nedenle fiyat talep esnekliği düşük pek çok piyasa malının yasal tekele konu edildiği ve bu yolla kamu finansman ihtiyacını karşılamanın amaçlandığı gözlenmektedir.

\section{Sonuç}

Çalışmada, Azerbaycan ekonomisinde fiyat oluşumuna etki eden Tarif Şurası'nın yapısı ve işleyişi ele alınmıştır. Piyasa ekonomisi kendine has kurum ve kurallara sahip olup, işlerliği piyasa kültürünü içselleştirmiş aktörlerin varlığına bağlıdır. Kapitalist ekonomik sisteme geçiş sürecini yaşayan Azerbaycan ekonomisinde serbest piyasa ekonomisinin yasal ve kurumsal altyapısının büyük ölçüde kurulduğu gözlenmektedir. $\mathrm{Bu}$ çerçevede rekabet kurumunun kurulmuş olması, finansal piyasalarının serbest piyasa ekonomi koşullarında çalışmalarını sağlayacak kurumsal yapının oluşturulması ve mal piyasaları ile koordinasyonu sağlayacak yapıların kurulması önemli gelişmeler olarak kabul edilebilir. Ancak serbest piyasa ekonomisinin gerekli kıldığı kurumsal yapıların oluşturulması kapitalist kültürün oluşması açısından tek başına yeterli değildir. Kapitalist kültürün oluşumu da ancak birkaç yönetim kuşağının piyasa ekonomisi içinde 
yaşamasını gerektirmektedir. Dolayısıyla, özel mülkiyet hakkının devlet tarafından yasal düzeyde tanınmış olması piyasa ekonomisine geçişin tamamlandığı anlamına gelmemektedir. Bu yönüyle değerlendirildiğinde serbest piyasa ekonomisinin işlerliğinin hakim kılınabilmesi ve piyasa kültürünün gelişebilmesi için pek çok yönetim kuşağının piyasa ekonomisi koşullarında yaşam sürmesi gerektiği söylenebilir.

Genç Azerbaycan Cumhuriyeti, kurucu kadro bir yana bırakılırsa, henüz ilk yönetim kuşağını dahi tamamlamamıştır. Dolayısıyla, ekonomik sistem olarak serbest piyasa ekonomisini benimsemiş olan Azerbaycan'ın 17 yıllık bağımsızlık tarihi piyasa ekonomisi kural ve kurumlarını tam anlamıyla kavraması ve işler kılması açısından oldukça kısa bir süredir.

\section{Kaynakça}

Akalın, G. (2016). Kamu Ekonomisi, Ankara: Orion Kitabevi

Azerbaycan Cumhuriyeti Bakanlar Kurulu, 'Devlet düzenlemesine alınan fiyatların oluşturulması ve uygulanmasına ilişkin devlet kontrolü kuralları', http://eqanun.az/framework/14583

Azerbaycan Cumhuriyeti Bakanlar Kurulu. Devlete kayıtlı ilaçların fiyatlarının düzenlenmesi ve bu fiyatların kontrolü ile ilgili yönetmelik kararı. http://eqanun.az/framework/30178

Azerbaycan Cumhuriyeti Bakanlar Kurulu. Tarifleri Devlet Tarafından Düzenlenen Malların (İ̧lerin, Hizmetlerin ) listesinin onaylanması üzerine karar. http://eqanun.az/framework/11342

Azerbaycan Cumhuriyyeti Muhasebe Odası. 2017 yılının ilk altı aylık döneminde temel makroekonomik göstergeler ve bütçe parametreleri analizi. http://sai.gov.az/upload/files/2017_6ayliq-icra_final.pdf

Besleyy, T. \& Perssonz, T. (2009). State Capacity, Conflict and Development. http://econ.Ise.ac.uk/staff/tbesley/papers/statecapacity.pdf 08.03.2018)

Cingolani, L. The State of State Capacity: a review of concepts, evidence and measures, Working Paper Series on Institutions and Economic Growth: IPD WP13, 2013. https://www.merit.unu.edu/publications/wppdf/2013/wp2013-053.pdf (Erişim: 07/03/2018).

Dinler, Z. (2015a). Iktisada Giriş, Bursa: Ekin Basım Yayın Dağıtım.

Dinler, Z. (2015b). Mikro Ekonomi, Bursa: Ekin Basım Yayın Dağıtım.

Edizdoğan, N. (2004). Kamu Maliyesi, Bursa: Ekin Kitabevi.

Herasimenko, V. (2005). Tsenoobrazovaniye, Moskova: Infra - M. 
https://news.milli.az/politics/318991.html (Erişim: 19.08.2017)

Işık, A. (2014). Kamu Maliyesi, Bursa: Ekin Basım Yayın Dağıtım.

Marx, K. (1865). Value, Price and Profit, Yayın tarihi: 1898.

Ottervi, M. (2013). Conceptualizing and Measuring State Capacity: Testing the Validity of Tax Compliance as Measure of State Capacity, The Qualıty Of Government Institute Working Paper Series.

Özel, H. (2009). Piyasa Ütopyası, Ankara: Bilgesu Yayıncılık.

Salimjanov, i. (2007). Tsenoobrazovaniye, Moskova: Knorus.

Şatah, C. (2014). 'Fayda-Maliyet Analizinde Uygulamada Karşılaşılan Güçlükler: Fayda Ve Maliyetin Belirlenebilme Sorunu', Süleyman Demirel Üniversitesi İktisadi ve Idari Bilimler Fakültesi Dergisi, C.19, S.1.

Şener, O. (2007). "Kamu Ekonomisinde Fiyatlama Politikası" Kamu Ekonomisi, (Ed.) Beyhan A., Eskişehir: Anadolu Üniversitesi Yayını, No. 789., Açık Öğretim Fakültesi Yayını, no. 1476.

Şener, O. (2016). Kamu Ekonomisi, 13. Baskı, Bursa: Beta Basım Yayım Dağıtım.

Şevçuk, D. (2008). Tsenoobrazovaniye, Moskova: Gross Media.

'2015 Yılında Azerbaycan Ekonomisi - rapor', http://caspianbarrel.org/az/2016/02/ 2015-ci-il-az-rbaycan-iqtisadiyyatinin-neftd-n-asililiq-numun-si-kimi-hesabat/

'Azerbaycan Ekonomisi Hakkında Genel Bilgiler', http://azerbaijan.az/portal/Economy/ General/generalInfo_01_a.html

'Tarif Şurası', http://www.tariffcouncil.gov.az/?/az/content/44/ 